\title{
Isolation and characterization of microsatellite markers in Atrina vexillum Born
}

\author{
Y.F. Ning ${ }^{1,2}$, Z.B. Li ${ }^{1,2}$, Y.S. Huang ${ }^{1,2}$, X.Q. Mao ${ }^{1,2}$, B.B. Li ${ }^{1,2}$, Y. Yuan ${ }^{1,2}$ and \\ J.B. Shangguan ${ }^{1,2}$ \\ ${ }^{1}$ Fisheries College, Jimei University, Xiamen, China \\ ${ }^{2}$ Fujian Provincial Key Laboratory of Marine Fishery Resources and Eco-Environment, \\ Xiamen, China \\ Corresponding author: Z.B. Li \\ E-mail: lizhongbao@jmu.edu.cn \\ Genet. Mol. Res. 15 (2): gmr.15027204 \\ Received July 14, 2015 \\ Accepted November 19, 2015 \\ Published April 4, 2016 \\ DOI http://dx.doi.org/10.4238/gmr.15027204
}

ABSTRACT. Atrina vexillum Born is an economically valuable species, widely distributed in the coastal waters of temperate and tropical areas of the Asia Pacific region. Twenty one novel microsatellite loci were identified in the genome of $A$. vexillum Born using the protocol for fast isolation by amplified fragment length polymorphism of sequence containing repeats. Thirty-two wild type individuals were used to evaluate the degree of polymorphism of these markers. We identified 13 polymorphic and 8 monomorphic loci with the number of alleles per locus and the polymorphism information content ranging from 2 to 5 and 0.141 to 0.664 , respectively. The observed and expected heterozygosity varied from 0.1250 to 0.7000 and 0.1223 to 0.6216 , respectively. Two loci deviated significantly from Hardy-Weinberg equilibrium (HWE) after Bonferroni correction, whereas the other loci were in HWE. These loci are expected to provide useful information for population genetic studies of $A$. vexillum Born.

Key words: Atrina vexillum Born; Microsatellites; Genetic markers 


\section{INTRODUCTION}

Atrina vexillum Born, belonging to the family Pinnidae, is an economically valuable species, widely distributed in the coastal waters of the temperate and tropical areas of the AsiaPacific region. In China, it is found mostly in the South China Sea (Wang, 1979). A large wedgeshaped bivalve, it commonly lives $20-50 \mathrm{~m}$ beneath the ocean floor. The natural population of $A$. vexillum Born has decreased considerably due to overexploitation because of its high commercial value and deteriorating habitat (Yu et al., 1999). In order to conserve genetic resources and assess genetic diversity in $A$. vexillum Born, it is necessary and important to isolate some polymorphic microsatellite markers for this shellfish.

Microsatellite DNA, also called simple sequence repeat or short tandem repeat consists of repeating nucleotide units 2-6 bp (Chen et al.,2012). Microsatellite markers are non-coding, highly polymorphic, co-dominant DNA markers, which are effective tools for genetic analysis. It has been widely used in population genetics, population differentiation, linkage analysis, and evolutionary studies (Rice and Pechenik, 1992; Xu et al., 2009). Previous studies on A. vexillum Born focused on its morphology and isozyme patterns (Wang and Yu, 2000). Eleven polymorphic microsatellite loci have been reported in A. vexillum Born. However, the population structure of this economically valuable species has been insufficiently studied, and studies on the development of genetic markers are urgently needed. In the present study, a novel marker suite of 21 loci in $A$. vexillum Born was developed, which may be useful in further studies on population genetics and measures for the protection of the species.

\section{MATERIAL AND METHODS}

Twenty one microsatellite markers were identified in $A$. vexillum Born using the fast isolation by amplified fragment length polymorphism of sequences containing repeats protocol (Zane et al., 2002). Total genomic DNA was extracted from the muscle tissue of a wild $A$. vexillum Born individual collected from Hainan, China, using the genomic DNA extraction kit (Tiangen, Beijing, China) according to the manufacturer instructions. DNA concentration was estimated using an ultraviolet spectrophotometer and by electrophoresis on a $1 \%$ agarose gel. The obtained DNA was diluted to $100 \mathrm{ng} / \mu \mathrm{L}$ followed by digestion with $10 \mathrm{U}$ restriction enzyme FastDigestTru1/ in a $25-\mu \mathrm{L}$ volume and incubation for $10 \mathrm{~min}$ at $65^{\circ} \mathrm{C}$. The digested fragments, ranging from 500 to $1200 \mathrm{bp}$, were purified and ligated to Msel adapter 1 (5'-ACGATGAGTCCTGAG-3')/Msel adapter 2 (5'-TACTCAGGACTCAT-3') by T4 DNA ligase (Fermentas, Vilnius, Lithuania) overnight at $22^{\circ} \mathrm{C}$. The digestion-ligation mixture was subsequently denatured and hybridized to the biotinlabeled oligo-nucleotide probes $(\mathrm{CT})_{15}$ and $(\mathrm{GT})_{15}$. Fragments containing microsatellite repeats were captured with Streptavidin-coated Magnetic Sphere Particles (Promega, Madison, WI, USA), and the unannealed DNA was washed away. The recovered products were amplified using Msel adapter1. The PCR products were purified to remove the extra dNTPs and adaptors. The purified products were ligated to pMD19-T vector (Takara, Shiga, Japan) and then transformed into Escherichia coli (Invitrogen, Carlsbad, CA, USA) for further selection on ampicillin plates.

A total of 178 positive clones were amplified via colony-PCR with universal M13 primers. DNA fragments above 500 bp were sequenced by Invitrogen (Shanghai, China); 146 sequences with microsatellites were successfully obtained. Forty eight primer pairs were designed using the Primer Premier version 5.0 (Singh et al., 1998). The amplification conditions for all the primers 
were optimized in an Eppendorf Mastercycler Gradient System (Eppendorf, Hamburg, Germany). Successful amplification primers were validated using the genomic DNA of 32 wild individuals of A. vexillum Born collected from Hainan Island, China. The 10- $\mu \mathrm{L}$ amplification reaction consisted of $50 \mathrm{ng}$ genomic DNA, 10X Taq buffer, $2 \mathrm{mM} \mathrm{MgCl}, 0.4 \mu \mathrm{M}$ each primer, $0.2 \mathrm{mM}$ each dNTP, and $0.25 \cup$ Taq DNA Polymerase (Fermentas). PCR was carried out under the following conditions: Initial denaturation at $94^{\circ} \mathrm{C}$ for $5 \mathrm{~min}$, followed by 37 cycles of denaturation at $94^{\circ} \mathrm{C}$ for $40 \mathrm{~s}$, annealing at an optimal temperature (Table 1) for $40 \mathrm{~s}$, and extension at $72^{\circ} \mathrm{C}$ for $1 \mathrm{~min}$, with a final elongation step at $72^{\circ} \mathrm{C}$ for $10 \mathrm{~min}$. The PCR products were electrophoresed on a $6 \%$ denaturing polyacrylamide gel in a Sequi-Gen Sequencing Cell (Bio-Rad, Hercules, CA, USA) and visualized using silver staining. Data matrices was analyzed to estimate the observed heterozygosity $\left(H_{0}\right)$, expected heterozygosity $\left(H_{\mathrm{E}}\right)$, number of alleles $\left(N_{\mathrm{A}}\right)$ and the polymorphism information content (PIC) by the software POPGEN 32 (version 1.32) and CERVUS 3.0 (version 3.0) (Yeh et al., 2000).

Table 1. Statistical information of 21 microsatellite loci in Atrina vexillum Born (32 individuals).

\begin{tabular}{|c|c|c|c|c|c|c|c|c|c|}
\hline GenBank accession No. & Locus ID & \begin{tabular}{|l|l} 
Primer sequences $\left(5^{\prime}-3^{\prime}\right)$ \\
\end{tabular} & Repeat motif & $\mathrm{Ta}\left({ }^{\circ} \mathrm{C}\right)$ & $N_{\mathrm{A}}$ & $\mathrm{PIC}$ & $\mathrm{Ho}_{\mathrm{O}}$ & $H_{\mathrm{E}}$ & Allele size (bp) \\
\hline KR704581 & Q-1 & $\begin{array}{l}\text { F: AACGCATCGTAACATTTTC } \\
\text { R: AGCCTACAGTTCACATCCC }\end{array}$ & $(\mathrm{GT}) 12$ & 51 & 4 & 0.460 & 0.2727 & 0.2495 & $183-195$ \\
\hline KR704582 & $\mathrm{Q}-2$ & $\begin{array}{l}\text { F: GACAAACGGACATACAGA } \\
\text { R: TCACGAAATTACATCCC }\end{array}$ & $(\mathrm{CT})_{17}$ & 55 & 4 & 0.382 & 0.1923 & 0.2451 & $130-154$ \\
\hline KR704583 & Q-3 & $\begin{array}{l}\text { F: GAATCTCGCTGAAATAAC } \\
\text { R: TGTCCCAGAACTGTCATA }\end{array}$ & $(\mathrm{TC})_{34}(\mathrm{TG})_{22}$ & 45 & 2 & 0.255 & 0.3667 & 0.3045 & $140-150$ \\
\hline KR704584 & Q-4 & $\begin{array}{l}\text { F: CCTAAATGACAATGAGCAG } \\
\text { R: GCAAAAATCGCTGTAGTAC }\end{array}$ & $(\mathrm{TG})_{42}$ & 48 & 4 & 0.445 & 0.6217 & 0.5033 & 173-191 \\
\hline KR704585 & Q-5 & $\begin{array}{l}\text { F: GAGATACCAAGAGTCAATG } \\
\text { R: GACTGCCAAGTAACAAA }\end{array}$ & $(\mathrm{AG})_{19}$ & 43 & 5 & 0.351 & 0.1250 & 0.1223 & $132-164$ \\
\hline KR704586 & $\mathrm{Q}-6$ & $\begin{array}{l}\text { F: GTTATGATCCCAAGAGC } \\
\text { R: AACGGACATACATACTGAC }\end{array}$ & $(\mathrm{CT})_{16} \mathrm{CC}(\mathrm{CT})_{46}$ & 54 & 3 & 0.420 & 0.7000 & 0.5011 & $210-232$ \\
\hline KR704587 & Q-7 & $\begin{array}{l}\text { F: ATTTCAAACGTAAAGGTTGTC } \\
\text { R: CAGTTCTTGTTGGTGGTGTA }\end{array}$ & $(\mathrm{AC})_{23}$ & 48 & 4 & 0.436 & 0.3200 & 0.2865 & $92-115$ \\
\hline KR704588 & Q-8* & $\begin{array}{l}\text { F: ATCTACCGATCCATAAGC } \\
\text { R: GTCATCCATTTCCCAAC }\end{array}$ & $(\mathrm{AC})_{26}$ & 46 & 4 & 0.664 & 0.2727 & 0.6216 & 134-167 \\
\hline KR704589 & Q-9* & $\begin{array}{l}\text { F: GTCACATTCATAAAACAA } \\
\text { R: CTCTGTCTACCCCATT }\end{array}$ & $(\mathrm{CT})_{12} \mathrm{~N}(\mathrm{CA})_{28}$ & 50 & 4 & 0.506 & 0.3750 & 0.3768 & $130-154$ \\
\hline KR704590 & Q-10 & $\begin{array}{l}\text { F: TAAAACAAGGCAAATAAG } \\
\text { R: CAAGACTGGTAGTAAAAGG }\end{array}$ & $(\mathrm{GT})_{18}$ & 53 & 3 & 0.193 & 0.2333 & 0.2130 & $160-175$ \\
\hline KR704591 & Q-11 & $\begin{array}{l}\text { F: AATTCGTATTCGTTCAC } \\
\text { R: CATAGGCTTCCTGTTT }\end{array}$ & $(\mathrm{CT})_{12} \mathrm{~N}(\mathrm{CA})_{28}$ & 51 & 3 & 0.227 & 0.2667 & 0.2441 & $143-158$ \\
\hline KR704592 & Q-12 & $\begin{array}{l}\text { F: CGTACAGACTGGAAGATGG } \\
\text { R: CGTTTTCACGGCTATTT }\end{array}$ & $(\mathrm{CT})_{5}$ & 49 & 2 & 0.141 & 0.1667 & 0.1554 & $126-137$ \\
\hline KR704593 & Q-13 & $\begin{array}{l}\text { F: GCTTTTAGTACTCCAAG } \\
\text { R: GAGATTTTGTTGTTGAA }\end{array}$ & $(\mathrm{AG})_{23} \mathrm{~N}(\mathrm{CAA})_{3}$ & 48 & 4 & 0.494 & 0.2105 & 0.2845 & $110-136$ \\
\hline KR704594 & Q-14 & $\begin{array}{l}\text { F: CGGACATACAGACTGACACG } \\
\text { R: CTGGGACACTCCTAATGAAAT }\end{array}$ & 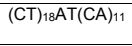 & 54 & NA & NA & NA & NA & 168 \\
\hline KR704595 & Q-15 & $\begin{array}{l}\text { F: TAACAGTTGTCCCTCTG } \\
\text { R: GACCAGATTTAGTTATTG }\end{array}$ & $(\mathrm{TG})_{16}(\mathrm{GA})_{15}$ & 42 & NA & NA & NA & NA & 227 \\
\hline KR704596 & Q-16 & $\begin{array}{l}\text { F: TTTTCCACAATCCTGT } \\
\text { R: ACTTTCCTATAAATCACTG }\end{array}$ & $(\mathrm{GA})_{12}$ & 52 & NA & NA & NA & NA & 125 \\
\hline KR704597 & Q-17 & $\begin{array}{l}\text { F: AATTGACATGTATTTTGTA } \\
\text { R: TATATCTAACTTTGGTTTT }\end{array}$ & $(\mathrm{TC})_{17}$ & 60 & NA & $\mathrm{NA}$ & NA & NA & 142 \\
\hline KR704598 & Q-18 & $\begin{array}{l}\text { F: CAAGTAGTGGAGGGTG } \\
\text { R: TCTTTATCTGTTACTGAAA }\end{array}$ & $(\mathrm{AC})_{39}$ & 50 & NA & NA & NA & NA & 210 \\
\hline KR704599 & Q-19 & $\begin{array}{l}\text { F: TTGTATTGTCCAAATGTC } \\
\text { R: ACTGAAAGATAAGGAGAAA }\end{array}$ & (CT) 10 & 54 & $\mathrm{NA}$ & NA & NA & $\mathrm{NA}$ & 125 \\
\hline KR704600 & $\mathrm{Q}-20$ & $\begin{array}{l}\text { F: GCTTTCTCGCTCCTGAAC } \\
\text { R: TGGTGGATGACACTCTTTACT }\end{array}$ & $(\mathrm{TC})_{17}$ & 53 & $\mathrm{NA}$ & $\mathrm{NA}$ & NA & NA & 223 \\
\hline KR704601 & Q-21 & $\begin{array}{l}\text { F: GAGATACCAAGAGTCAATG } \\
\text { R: GACTGCCAAGTAACAAA }\end{array}$ & $(\mathrm{AG})_{19}$ & 43 & NA & NA & NA & NA & 155 \\
\hline
\end{tabular}

$\mathrm{Ta}=$ annealing temperature; $N_{\mathrm{A}}=$ number of polymorphic alleles per locus; $\mathrm{PIC}=$ polymorphism information content; $H_{\mathrm{O}}=$ observed heterozygosity; $H_{\mathrm{E}}=$ expected heterozygosity, *highly significant deviations $(\mathrm{P}<0.0038)$ of locus from Hardy-Weinberg equilibrium after Bonferroni correction $(k=13)$.

\section{RESULTS}

Twenty one novel microsatellite markers were successfully amplified (Table 1); these included 13 polymorphic microsatellite loci and 8 monomorphic loci. The $N_{\mathrm{A}}$ and the PIC ranged from 2 to 5 and 0.141 to 0.664 , respectively. The $H_{\mathrm{O}}$ and $H_{\mathrm{E}}$ varied from 0.1250 to 0.6217 and 0.1223 to 0.6216 , respectively. Deviations from the Hardy-Weinberg equilibrium (HWE) and genotypic 
linkage disequilibrium were tested using POPGENE 32 (version 1.32). Most loci were in HWE (P > $0.05)$, except locus $Q-8$ and $Q-9$, even after sequential Bonferroni correction $(P<0.0038)$.

DISCUSSION

Many reasons could contribute to this result, such as natural selection, inbreeding, the Wahlund effect, null alleles, and size homoplasy (Dai et al., 2013). Also, the small sample size could account for the significant deviations from HWE. Therefore, to reveal the accurate genetic background of wild type $A$. vexillum Born, more sample areas and larger sample sizes should be used for further studies.

The loci characterized in this study may be useful for further analysis of the genetic diversity and structure of $A$. vexillum populations, and for designing conservation strategies for $A$. vexillum Born.

\section{Conflicts of interest}

The authors declare no conflicts of interest.

\section{ACKNOWLEDGMENTS}

Research supported by the Natural Science Foundation of the Fujian Province (Grant \#2014J01133), the National Natural Science Foundation of China (Grant \#31272668), the Foundation for Innovative Research Team of Jimei University, China (Grant \#2010A004), and the Program for New Century Excellent Talents in the Fujian Province University [\#(2006)35].

\section{REFERENCES}

Chen XJ, Li ZB, Chen L, Cao YY, et al. (2012). Isolation and characterization of new microsatellite markers in the pen shell Atrina pectinata (Pinnidae). Genet. Mol. Res. 11: 2884-2887. PubMed http://dx.doi.org/10.4238/2012.May.22.4

Dai G, Li Y, Li Z, Li Q, et al. (2013). Isolation and characterization of twelve novel polymorphic microsatellite loci in the Branchiostoma belcheri Gray (Amphioxus). Conserv. Genet. Resour. 5: 1115-1116. http://dx.doi.org/10.1007/s12686$\underline{013-9966-9}$

Rice MA and Pechenik JA (1992). A review of the factors influencing the growth of the northern quahog, Mercenaria mercenaria (Linnaeus, 1758). J. Shellfish Res. 11: 279-287.

Singh VK, Mangalam AK, Dwivedi S and Naik S (1998). Primer premier: program for design of degenerate primers from a protein sequence. Biotechniques 24: 318-319. PubMed

Wang MF and Yu XY (2000). Study on electrophoretograms of isozymes from different tissues of Atrina vexillum Born. Mark. Sci. 24: 14-16.

Wang ZR (1979). Precious marine product, Pinnidae. Mark. Sci. 2: 54-56.

Xu XJ, Wang GZ, Wang KJ and Li SJ (2009). Isolation and characterization of ten new polymorphic microsatellite loci of the mud crab, Scylla paramamosain. Conserv. Genet. 10: 1877-1878. http://dx.doi.org/10.1007/s10592-009-9843-y

Yeh FC, Yang R, Boyle TJ, Ye Z, et al. (2000). PopGene32, Microsoft Windows-Based freeware for Population Genetic analysis. Version 1.32. Molecular Biology and Biotechnology Centre, University of Alberta, Alberta.

Yu XY, Wang MF and He ZJ (1999). Study on early embryonic development of Atrina vexillum Born. Mark. Sci. 4: 62-65.

Zane L, Bargelloni L and Patarnello T (2002). Strategies for microsatellite isolation: a review. Mol. Ecol. 11: 1-16. PubMed http://dx.doi.org/10.1046/j.0962-1083.2001.01418.x 